\title{
A Tale of Two Rivers: Can the Restoration Lessons of River Thames (Southern UK) Be Transferred to River Hindon (Northern India)?
}

\author{
Vasker Sharma (Dimanshu Joshi • \\ Michael J. Bowes
}

Received: 16 April 2020 / Accepted: 21 April 2021 / Published online: 10 May 2021

(C) The Author(s), under exclusive licence to Springer Nature Switzerland AG 2021

\begin{abstract}
This study identifies the basin scale factors and potential remedies to restore the severely polluted Hindon River in India, by comparing with another basin with high population density: the River Thames in the UK. Biochemical oxygen demand (BOD) and dissolved oxygen (DO) in the Thames River are usually around 8 $\mathrm{mg} / \mathrm{l}$ and $7.5 \mathrm{mg} / \mathrm{l}$ respectively, while phosphorus and ammonium range between $0.1-0.6 \mathrm{mg} / 1$ and $0.1-0.4$ $\mathrm{mg} / \mathrm{l}$ respectively. The Thames has seen great improvements in water quality over the past decades, due to high levels of sewage treatment and regulation of industrial effluents which have improved water quality conditions. Conversely, the Hindon River suffers from extremely poor water quality and this is mainly attributed to the direct discharge of partially treated or untreated municipal and industrial wastewater into the river. BOD is in the range of $15-60 \mathrm{mg} / \mathrm{l}$ and DO is below $5 \mathrm{mg} / \mathrm{l}$. Phosphorus ranges around $2-6 \mathrm{mg} / \mathrm{l}$ at most of the
\end{abstract}

\footnotetext{
V. Sharma $(\bowtie)$

Department of Civil Engineering and Surveying, Jigme Namgyel Engineering College, Royal University of Bhutan, Dewathang, Samdrupjongkhar, Bhutan

e-mail: vaskersharma@jnec.edu.bt

H. Joshi

Department of Hydrology, Indian Institute of Technology,

Roorkee, India

e-mail: joshifhy@iitr.ac.in

M. J. Bowes

UK Centre of Ecology \& Hydrology, Maclean Building, Benson Lane, Crowmarsh Gifford, Wallingford, Oxfordshire OX10 8BB, UK

e-mail: mibo@ceh.ac.uk
}

monitoring stations and ammonia-nitrogen in the range of $10-40 \mathrm{mg} / 1$ in Galeta at Hindon. The analysis of variance also depicts the spatial and temporal variation in water quality in the Hindon River. Besides, non-point sources, pollution from point sources with minimal base flow in the river during dry season, result in low dilution capacity causing high pollutant concentrations which impacts the river ecosystem and fisheries. To restore the Hindon River, resources must be focussed on mainly treating sewage and industrial effluents and by developing appropriate river basin management and regulatory plans.

Keyword Pollution · River restoration - Strategic management plans $\cdot$ ANOVA $\cdot$ Sewage

\section{Introduction}

The natural environment has faced an increasing pressure due to continuing economic development, leading to significant degradation of ecosystems. Owing to the society's demand for goods and services, biodiversity has been reduced on a global scale and the aquatic and terrestrial ecosystem is at stake. Rivers around the globe have been used as the main source of fresh drinking water and for irrigation purposes, but due to industrial and urban pollution, the water in many rivers has been rendered undrinkable and even unfit for agriculture. Degradation of rivers has also resulted due to few water resource management measures in the past, such as straightening of water channels and regulation of flow 
and water storage. This in turn has resulted in increased erosion and sediment loads, reduced water quality and increased flooding. Further it has also posed a threat to the diversity of riverine habitats (Loucks \& Avakyan, 1998). Nevertheless, the primary reason for the degradation of rivers around the world is attributed to the discharge of wastewater from the habitations located along the river. The growing population, urbanization and industrialization have been posing a significant threat to river water quality, disrupting the ecological functioning of the river due to degradation of instream and riparian habitats. Over the past decades, the practice of river restoration has gained ground and even few studies have been reported to evaluate whether the restoration projects achieve the goals of improving the river and attaining good ecological status (Bernhardt et al., 2005; Bernhardt \& Palmer, 2011). Duel et al. (2002) and Baptist et al. (2004) proposed the restoration of rivers based on flood conveyance and enabling the biodiversity at the same time; however, Woolsey et al. (2007) also considered ecological indicators for rejuvenating the river, where restoration success is evaluated based on the pre- and post-ecological indicators. Palmer et al. (2005) also proposed few criteria for measuring the restoration of a river, which includes ecological consideration of the river system, resilience of river system to external disturbances and pre-post assessment of restorative activities among others. Restoration of river has been referred to include plethora of activities including channelization of rivers for improving aesthetic and recreational purpose, flood plain reconnection, flow modification, land acquisition, water quality improvement, instream habitat management and improvement (Morandi et al., 2017; Wohl et al., 2015). The USA has put major efforts to restore streams since the late 1800 s, and over \$1 billion USD annually was spent on restoration to improve or repair degraded US streams and rivers (Bernhardt et al., 2005; Palmer et al., 2005). Restoration of the Danube River began in the 1940s, and since then, restoration has been undertaken across much of the $2800 \mathrm{~km}$ length of the Danube and its tributaries (Speed et al., 2016). Szalkiewicz et al. (2018) showed that the restoration of 1 ha of European rivers may cost up to $€ 0.312$ million. Restoration frameworks based on institutional guidelines, vegetative buffer along river corridor and channelizing though have reportedly aided in restoring flood-eroded degraded river corridors (Mondal \& Patel, 2018); however, such approach may not be feasible for rivers with degraded water quality due to release of high amount of untreated sewage. Restoration strategies adopted via physical or instream modification of channel may not be effective in achieving long-term restoration goals, and it may be rather advisable to focus on improving the ecology of the river system (Johnson et al., 2020; Theodoropoulos et al., 2020). Further, the ecological knowledge of a region and involvement of stakeholder for the river restoration project should also be considered for effective restoration (Szałkiewicz et al., 2020). Modelling study by Abdi et al. (2020) emphasized that maintaining natural bedforms, riparian shading and riparian forest helped in lowering the temperature of the urban river and increasing the saturated dissolved oxygen level thereby rendering the environment conducive for terrestrial ecosystem.

Interestingly, Dutta et al. (2020) found the evidence of increased DO concentration and decreased BOD and nitrate concentration during the Covid-19 lockdown period, which was basically associated with reduced water use by industries and urban-agricultural activities. Kumar et al. (2020) also advocated the reduction of domestic discharge for river restoration, in order to increase the rejuvenation capacity of the river Ganga in India. Upadhyay et al. (2019) have proposed economic and cost-effective restoration approaches based on wetland construction along the river stretches to minimize the pollution loads and also to provide the habitat for the river biodiversity. Stoffers et al. (2021) have recently reported that introducing and maintaining permanent flow regime in the channels helps in maintaining a thriving aquatic ecosystem and thereby achieving the desired restoration goals.

The Hindon River in India, which is a tributary of the Yamuna River having most of its basin area in the state of Uttar Pradesh, has been classified as "Class E" (severely polluted river) by Central Pollution Control Board (CPCB) due to the poor condition in the river, which is attributed to the discharge of wastewater from both the municipalities and industries along its length. The concentration of the pollutants is so high that it is unable to support the propagation of river flora and fauna. A previous study of this River from Nagdev nala (wastewater drain) in Saharanpur to Hindon cut in the city of Ghaziabad reported that the dissolved oxygen in the upstream section was satisfactory, but a critical situation was observed below the locations demonstrating inputs of major municipal and industrial effluent outlets to the river (National Institute of Hydrology, 
1999). Numerous other studies have highlighted the excessive pollution in the Hindon river (Jain \& Sharma, 2001; Janhit Foundation, 2007; Ranjan \& Singhal, 2014; Rizvi et al., 2015; Sharma et al., 2014; Suthar et al., 2010). Janhit Foundation (2007) also reported the adverse implications for groundwater contamination on the health of the community downstream of Saharanpur due to possible river-aquifer interaction manifesting itself in the form of pollution of both surface water and groundwater with toxic organochlorine and organophosphorus pesticides, which disrupt the endocrine system in the human body.

The River Thames (UK) faced similar problems, related to the expanding population of the city of London, and rapid economic development from the onset of the Industrial Revolution and into the twentieth century. The water quality and ecology of the River Thames was greatly damaged as the human waste produced by the population was directly routed into the river. This caused widespread and regular outbreaks of cholera, and resulted in "The Great Stink" of 1858, during which the smell from the river forced Parliament to close (Hillier \& Bell, 2010). This ultimately led directly to the UK Government undertaking large-scale sanitation improvements and the building of sewage treatment works (STWs) which transformed the ecological health of the Thames.

In this study, these two rivers (say basins) were selected for comparison owing to the similar population density, extent of urban sprawl and quite comparable point and non-point sources of pollutants being discharged into the rivers, viz. municipal, industrial etc. One more factor was the availability of the credible and comparable information about both the systems. The details of the two rivers are as shown in Table 1. It is aimed to compare the status of river water quality of both rivers under external stress, challenges faced and success achieved specially in restoration of Thames river quality, so as to develop an insight for developing suitable environmental plans for Hindon river.

\section{Methods}

\subsection{Study Area}

\subsubsection{Hindon Basin}

The Hindon River is a tributary of the upper Yamuna River, covering an area of $4200 \mathrm{~km}^{2}$ at Galeta gauging station in Meerut, where gauge, discharge and water quality (GDQ) are being monitored by the Central Water Commission, India. The entire basin covers a geographical area of around $7000 \mathrm{~km}^{2}$ (Sharma et al., 2014) up to the confluence with the Yamuna River. The Hindon River traverses a distance of about $400 \mathrm{~km}$ from its origin in Shivalik Hills to its confluence with the Yamuna River (Fig. 1a) with a mean flow of 35.4 cumecs being observed at Galeta. The annual rainfall in this rainfed basin is $800 \mathrm{~mm}$. The basin covers the administrative districts of Saharanpur, Muzaffarnagar, Meerut, Baghpat, Ghaziabad and Noida from western Uttar Pradesh and Haridwar from Uttarakhand state, India. The study area forms a part of vast IndoGangetic plain which is geologically composed of Quaternary young alluvium to Quaternary older alluvium (CGWB, 2012). The young alluvium is composed of clay, silt and older alluvium composed of silt, sand, gravel and lithomargic clay. The sequence of loose gravel, sand and silt of flood plains of the river, comprises of channel alluvium. The deposits of sand beds of varying thicknesses are the main sources of groundwater, sustaining both the domestic and irrigation needs in the area (Babbar et al., 2009).

\subsubsection{Thames Basin}

The River Thames has the second largest river basin in the UK, $9948 \mathrm{~km}^{2}$ (Fig. 1b) at the tidal limit at Teddington in southwest London, at which there has been continuous monitoring of river flow and water quality since 1867 . The River Thames is a major source of water for industrial and domestic purposes, but it is also a major receiver of domestic and industrial effluent. The river flows for $240 \mathrm{~km}$ from its source in Gloucestershire to the tidal limit at Teddington, where the mean flow is 65 cumecs (Centre of Ecology and Hydrology, 2016). The western parts of the Thames basin are predominantly rural, whereas, the highly urbanized area of Greater London is located in the eastern part of the basin. The basin is home to about 14 million people. Just over $40 \%$ of public water supplies in the basin, equivalent to $2.25 \mathrm{BLD}$, come from groundwater, mainly from the Chalk aquifer in the middle and lower parts of the basin. The upper basin is underlain by Oolitic Limestone with calcareous pelo-alluvial gley soils. The average rainfall in the basin is $750 \mathrm{~mm} /$ year (Marsh \& Hannaford, 2008). The attributes of both the basin are compiled in Table 1. 
Table 1 Basin scale factors for both the basin

\begin{tabular}{lll}
\hline Factors & Hindon & Thames \\
\hline Area of the basin $\left(\mathrm{km}^{2}\right)$ & 7000 & 9948 \\
Length of river $(\mathrm{km})$ & 400 & 240 \\
Population density $\left(\mathrm{pop} / \mathrm{km}^{2}\right)$ & $1341(2011), 1602.85(2021)$ & $1407(2018)$ \\
Agriculture (\%) & 87.16 & 35.7 \\
Built up (\%) & 7.5 & 14.2 \\
STW (nos.) & 15 & 357 \\
Mean flow (cumecs) & 35.4 & 65.4 \\
Source of river flow & Rainfall and ground water & Rainfall, ground water and snowmelt \\
Annual average rainfall (mm/year) & 800 & 750 \\
Soil type & Quarternary Young Alluvium & Calcareous pelo-alluvial gley soils \\
Industries (nos.) & 473 & NA \\
Treated wastewater & 302.39 MLD & 4.4 BLD \\
\hline
\end{tabular}

\subsection{Data Availability}

The monthly water quality data ranging from 1997 to 2016 for the Hindon basin was collected from Department of Civil Engineering, Indian Institute of Technology, Roorkee (IITR) and Central Water Commission (CWC), India. The monitoring locations along Hindon River are as shown in Fig. 1. The weekly water quality data for the Thames basin was produced for seven sites along the Thames between 1997 and 2017 by the Centre of Ecology \& Hydrology, UK, as a part of the Thames Initiative Research Platform (Bowes et al., 2018). Data was downloaded from the Environmental Information Data Centre (https://doi.org/10.5285/e4c300b1-8bc34df2-b23a-e72e67eef2fd). Further, weekly biochemical oxygen demand (BOD) data from 1974 to 1977 and weekly dissolved oxygen (DO) data from 1974 to 2010 were obtained from the Environment Agency in the UK. The comparison of river water quality has mainly been done between Galeta station in Hindon and Wallingford station in Thames owing to the availability of data of mostly common water quality variables at these sites. The variables such as BOD, DO, phosphorus, chlorides, sulphates and nitrogen are found

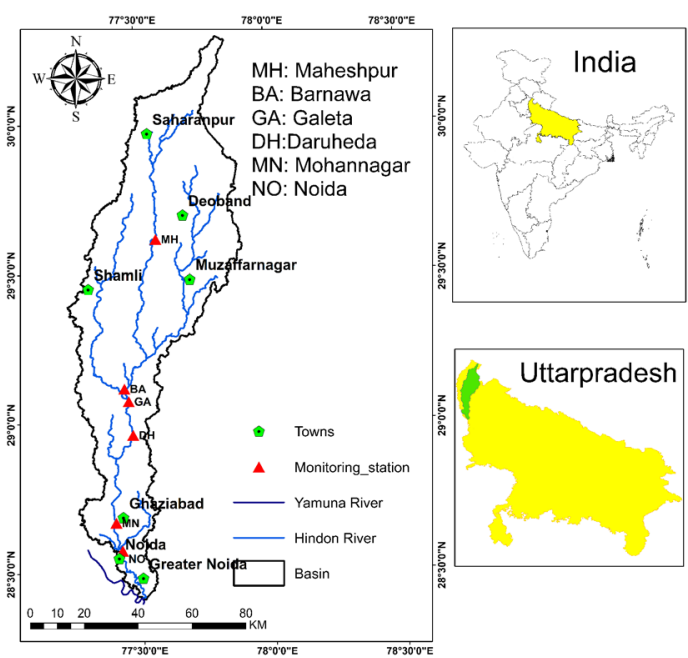

(a)

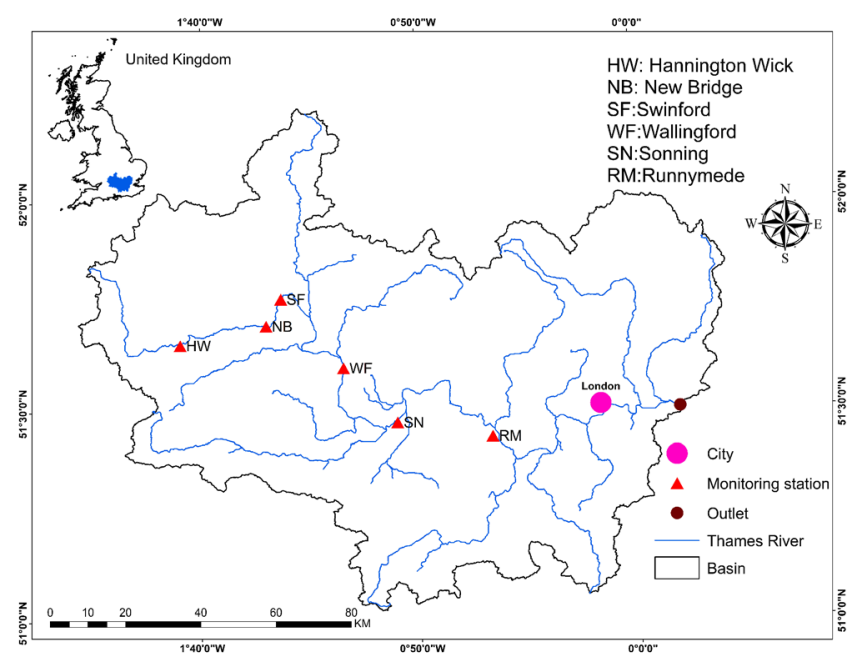

(b)

Fig. 1 Study area. a Hindon basin in India. b Thames basin in UK 
common to both the stations. However, it may also be noted that the forms of nitrogen were reported as ammonia-nitrogen at Galeta and ammonium ion at Wallingford respectively. Nitrate (other form of nitrogen) was also monitored at Wallingford besides other variables, which was not observed at Galeta. BOD and DO were monitored at all the monitoring stations of Hindon River; however, it was monitored only at Wallingford in Thames. BOD and DO represented the state of the rivers under the influence of organic compounds, while phosphorus contribution could be attributed to the agricultural fields and urban areas from the basin. Chlorides and sulphates were more representative of the basin's sediments and geology, along with some influence of municipal-industrial effluents also.

Few limitations in the data were regarding their availability till 2016-2017 and some missing values owing to the limitation in accessibility, intermittent operational issues and occasional discontinuation of monitoring works. However, with the available set of data from both the rivers, the main objectives of adequately highlighting the comparative scenario of water quality status between rivers Hindon and Thames as in Fig. 2 and Fig. 3, and the role of restoration measures thereof could be adequately demonstrated.

\section{Results: River Quality Analysis}

\subsection{Assessment of Spatio-temporal Variability of Hindon River}

Detailed analysis of variability was conducted for the Hindon River to have a better understanding of the nature of change in the pollution status. The water quality data analysis was performed in R using ARTool package (Wobbrock et al., 2011) and other packages like ggplot2 (Wickham, 2016) and Performance Analytics (Peterson et al., 2018). Prior to applying any tests, the data was first checked for normality using ShapiroWilk's (SW) and Kolmogorov-Smirnov (K-S) tests for both the test $(p<0.05)$, indicating non-normality of the data. Therefore, non-parametric test was adopted to assess the spatial and temporal variance in water quality.

Nonparametric equivalent of one-way analysis of variance (ANOVA) using Friedman test was performed for studying the spatio-temporal variability demonstrated by the water quality data of Hindon River. From the Friedman test (Table 6 and Table 7 in Appendix), it was found that all the water quality variables (except for $\mathrm{pH}$ ) vary significantly over different monitoring stations $(p<0.05)$, and hence the null hypothesis of no variance in water quality was rejected at $5 \%$ significant level. It was also noted that water quality variables also varied significantly over different seasons $(p<0.05)$, except for BOD, $\mathrm{pH}$ and phosphorus $(p>0.05)$, thereby leading to the rejection of null hypothesis at $5 \%$ significance level. However, since the multiple factors like seasons and stations were involved in the data analysis, it was construed that the application of the nonparametric tests like Friedman test alone was inadequate, as they are unable to examine interaction effects.

To resolve this issue, another non-parametric test called aligned rank transform (ART) was carried out to account for the interaction effects between factors (seasons and stations). The non-parametric equivalent of two-way ANOVA, known as aligned rank transform (ART), can perform multiple factorial analysis. The ART relies on a pre-processing step that "aligns" data before applying averaged ranks, after which point common ANOVA procedures can be used, making the ART accessible to anyone familiar with the F-test. The ART

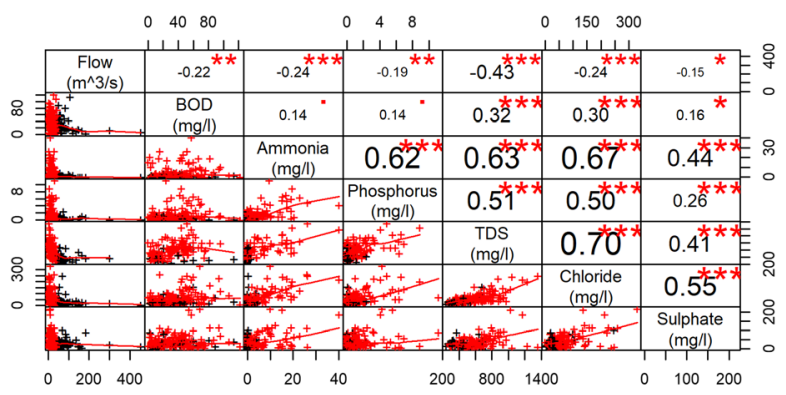

(a)

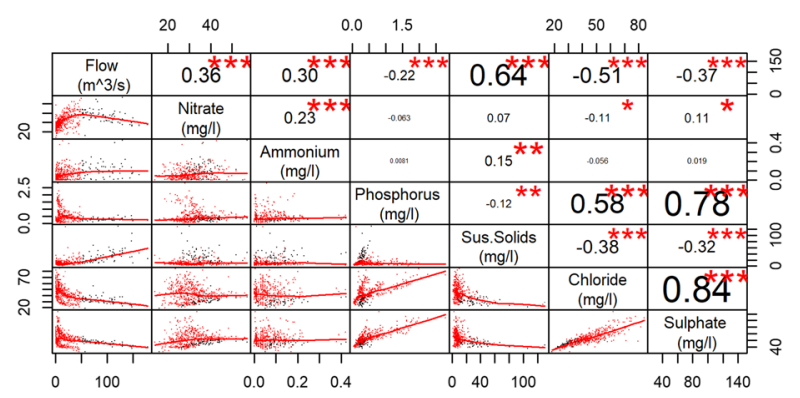

(b)

Fig. 2 Correlation matrix of the a River Hindon at Galeta and $\mathbf{b}$ River Thames at Wallingford ( $p$-values $0=* * *, 0.001=* *, 0.01=*, 0.05=$.] 

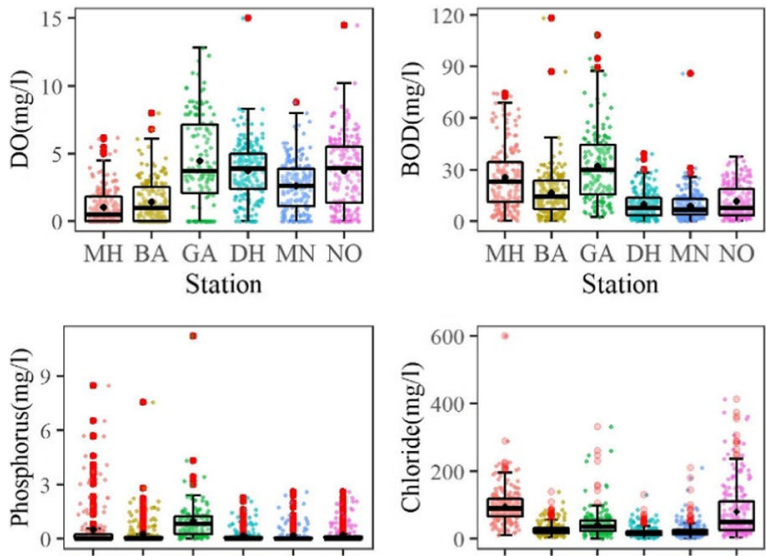

(a) $\mathrm{MH} \mathrm{BA}$ GA DH MN NO Station

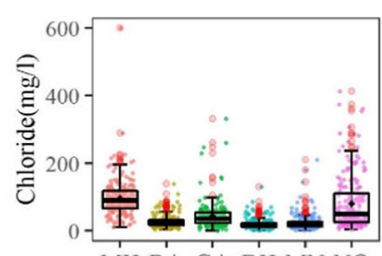

MH BA GA DH MN NO Station
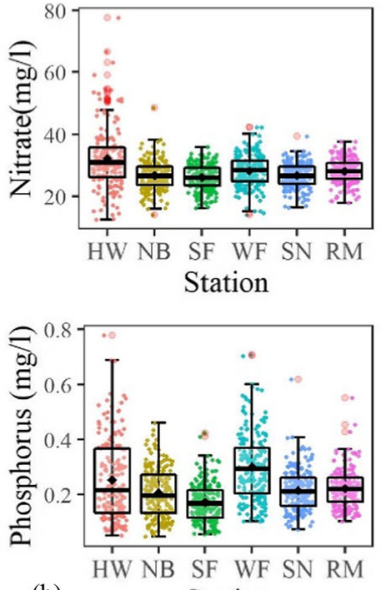

(b) Station
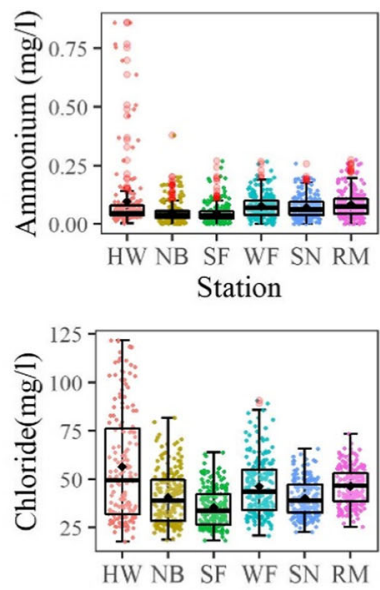

Station

- Mean

Fig. 3 Water quality along monitoring station at a Hindon and $\mathbf{b}$ Thames (note the differences in y axis between the two basins for phosphorus)

is for use in circumstances similar to the parametric ANOVA, except that the response variable may be continuous or ordinal, and is not required to be normally distributed (Wobbrock et al., 2011). Aligned rank transform test was carried out on the data. To ensure the correctness of the method, a full-factorial ANOVA performed on the aligned (not ranked) responses was checked $(\mathrm{F}=0.00, p=1.00)$, which showed that all the effects were stripped out. Further column sums of aligned responses were also checked for zero. The test statistics revealed that F-value and $p$-value were approximately equal to 0 and 1 respectively. After ensuring the correctness of the method, it was necessary to find out the exact location and season where the significance lies. Therefore, post hoc analysis was performed on the data to know the interaction among different factors. Post hoc interaction has only been shown for the interactions which are significant, i.e. $p<0.05$ which is as shown in Tables 8, 9, 10 and 11 in Appendix. From the test result of Friedman test and aligned rank transform test, the null hypothesis was rejected at 5\% significance level, denoting that water quality variables significantly varied both spatially (along monitoring station) and temporally (among seasons).

\subsection{Assessment of Association Among Water Quality Variables and with Flow}

From the above correlation plot (Fig. 2a), it is observed that all the water quality variables in the River Hindon significantly correlate negatively with flow. All the variables marked with asterisk (*) and a period (.) are found significantly correlating with the flow and other water quality variables. This may be attributed to a heavy continuous influx of point inputs and their dilution as flow increases (Bowes et al., 2008). It is also observed that ammonia-nitrogen, phosphorus, total dissolved solids and chlorides positively correlate with each other which signifies that these variables are possibly from the similar sources. For the Thames at Wallingford (Fig. 2b), phosphorus, chloride and sulphate also correlated negatively. This indicated that despite the significant improvements to the Thames basin's wastewater infrastructure, sewage effluent was still a major source, particularly during low flows during the ecologically sensitive spring and summer periods (Bowes et al. 2014). Suspended solids and ammonia-nitrogen exhibit slightly positive correlation with flow signifying that these loads are based on wash off from the basin.

\subsection{Assessment of River Water Quality Status Along Its Length and During Different Seasons}

To visualize the variation of water quality variables, the data points have been overlaid over the boxplot in Fig. 3 and Fig. 4. It is observed that Hindon basin exhibits poor water quality conditions (Fig. 3a). On an average (marked with •), DO is less than $5 \mathrm{mg} / \mathrm{l}$ at all the monitoring stations located along the river and minimum value of DO is usually observed during spring and 


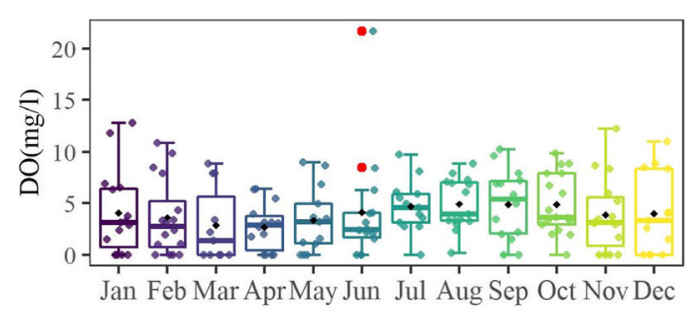

(a)

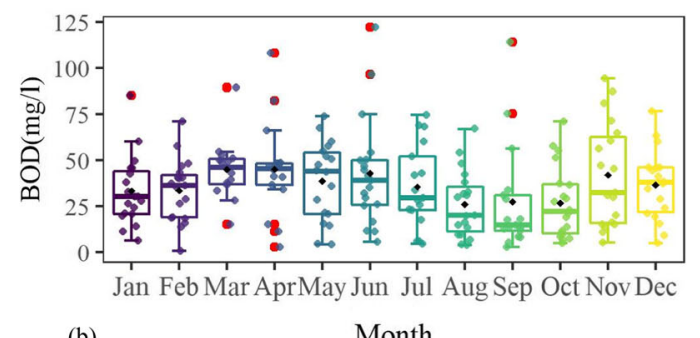

(b)

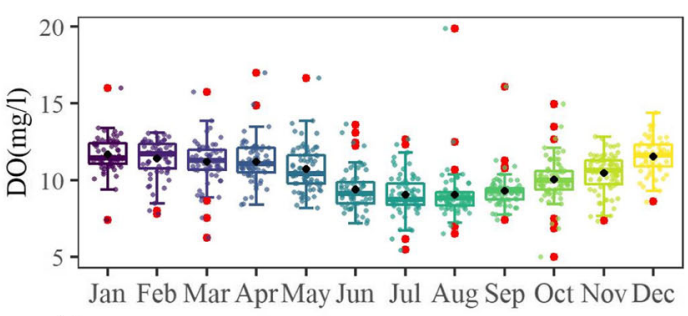

(c)

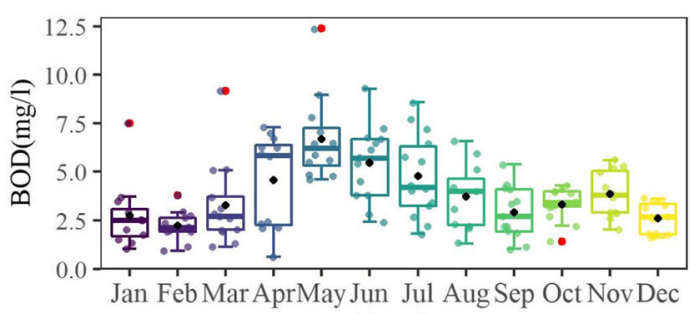

(d) Month

Fig. 4 Monthly variation of DO and BOD at Galeta in Hindon $(\mathbf{a}, \mathbf{b})$ and at NSWC intake in Thames (c, d) (note the different y-scale used for the two rivers)

summer (Fig. 4a), while BOD is in the range of 15 to 60 $\mathrm{mg} / \mathrm{l}$ at all the monitoring stations. Maximum BOD is usually observed during March, April and May (Fig. 4b) which correspond to low flow conditions in the river. It is also observed that a non-conservative nutrient like phosphorus ranges around $2-6 \mathrm{mg} \mathrm{P} / 1$ at most of the monitoring stations and it is usually lower during the summer monsoon season apparently due to a higher amount of flow in the river which tends to dilute the phosphorus concentration. However, the presence of outliers also depicts the sudden rise in phosphorus concentration which may be attributed to a sudden discharge of industrial and municipal waste. Since ammonia-nitrogen and sulphates are monitored only at Galeta in Hindon, their variation along the stretch of river could not be observed.

The River Thames exhibits a better water quality conditions for most measured variables. Nutrients like phosphorus and nitrates typically range between $0.1-$ $0.6 \mathrm{mg} \mathrm{P} / 1$ and $10-60 \mathrm{mg} \mathrm{NO} / 1$ respectively along all the monitoring stations along the Thames (Fig. 3b). The nutrients like nitrate and ammonium have higher concentrations during the autumn/winter period and lowest concentration during summer and spring, indicating predominantly diffuse, rain-related sources. However, increased concentration of total phosphorus is seen during summer and autumn low flow periods, indicating predominantly point source continuous inputs (Bowes et al., 2008). On an average (marked with •), DO is always greater than $8 \mathrm{mg} / \mathrm{l}$ and BOD is less than $7.5 \mathrm{mg} /$ 1 at the Lower Thames near Runnymede (Fig. 4c, d).

\subsection{Long-term Observation of Common Water Quality Variables in Both the Rivers}

Long-term water quality data from Galeta station was compared alongside with data from Wallingford station due to availability of data on common water quality variables, not available at other monitoring stations. The analysis of the long-term time series plots of water quality variables in Hindon River (Fig. 5a, b, c, d) shows that concentration of all the water quality variables continues to rise, indicating from the gross inadequacy in the sewage and industrial wastewater treatment from the basin. Phosphorus, chloride and ammonia-nitrogen show significant increase after 2013 indicating intensive nutrient inputs from agricultural activities and increasing industrialization and urbanization. In the Thames basin, on the other hand, concentration of the water quality variables shows a consistent decrease over the last two decades.

The annual average phosphorus concentration shows a reduction from $2 \mathrm{mg} \mathrm{P} / 1$ in 1997 to $0.2 \mathrm{mg} \mathrm{P} / 1$ in 2012 (Fig. 5e, f, g, h), due to the installation of tertiary sewage treatment units along with other measures. It has also been observed that the phosphorus concentrations at low flows have also been reduced (Fig. 6e), indicating reduction in constant point-source inputs (Bowes et al., 


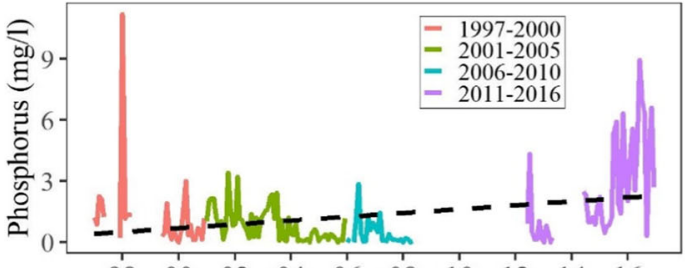

(a) $\begin{array}{llllllllll}98 & 00 & 02 & 04 & 06 & 08 & 10 & 12 & 14 & 16\end{array}$

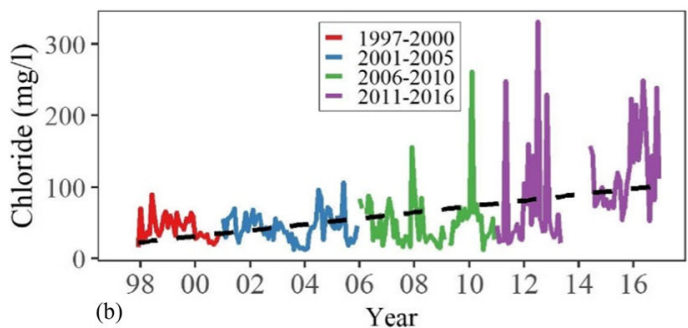

(b)

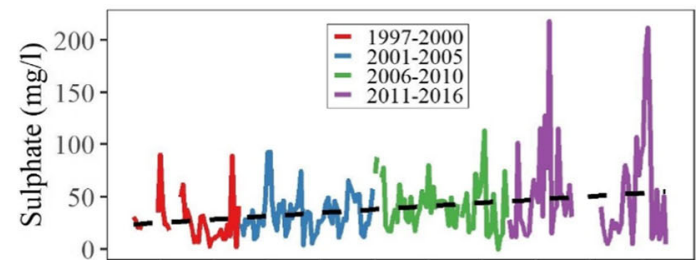

(c) $\begin{array}{lllllllllll}98 & 00 & 02 & 04 & 06 & 08 & 10 & 12 & 14 & 16\end{array}$ Year

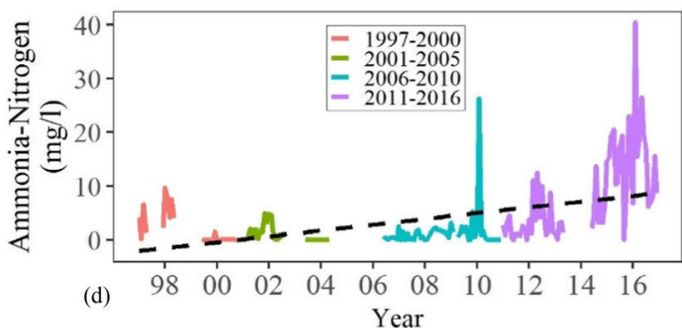

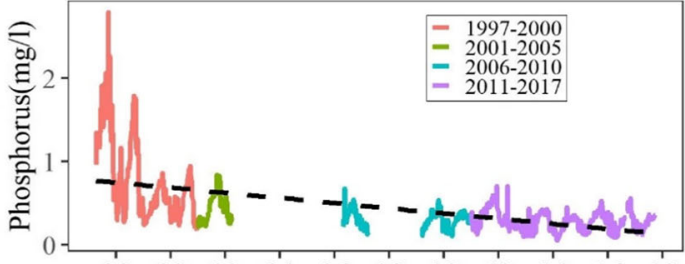

(e)
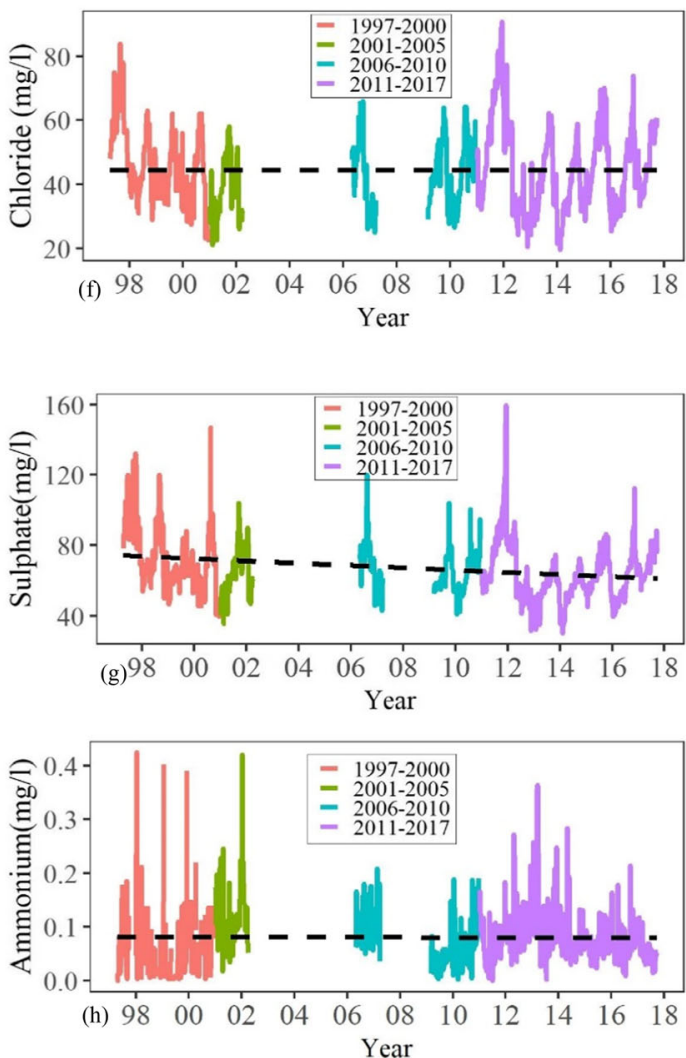

Fig. 5 A time series depicting changes in concentration at Galeta in Hindon $(\mathbf{a}, \mathbf{b}, \mathbf{c}, \mathbf{d})$ and Wallingford in Thames (e, f, $\mathbf{g}, \mathbf{h})$ (note the different $\mathrm{Y}$ axis scales used for each river basin)

2018). In contrast, the concentrations of phosphorus and ammonia-nitrogen at Galeta show an increase at low flows since 2011 (Fig. 6a, d), indicating increasing load of constant point-source inputs, most likely from point and non-point source inputs.

\subsection{Role of Rainfall Characteristics on River Quality}

It is universally accepted that the meteorological and hydrological (both river and basin hydrology) factors significantly influence quality of any river. The dilution capacity of the river is invariably enhanced by increased rainfall and increased base flow (Dutta et al., 2020). The two basins were also compared for their rainfall pattern to understand the monthly rainfall pattern. Rainfall data for Hindon basin was collected from Indian Meteorological Department (IMD) for the period of 26 years [1990 to 2015], while rainfall data for Thames basin were downloaded from https://catalogue.ceh.ac. uk/documents/5dc179dc-f692-49ba-9326-a6893a503f6 e for the same time period. Using the Thiessen polygon, mean areal rainfall was calculated (Fig. 7) for both basins. On average, the Thames basin receives an annual rainfall of $700 \mathrm{~mm}$ while Hindon basin receives an annual rainfall of $800 \mathrm{~mm}$. Rainfall pattern of the two basins presents quite a contrast. From the mean areal 


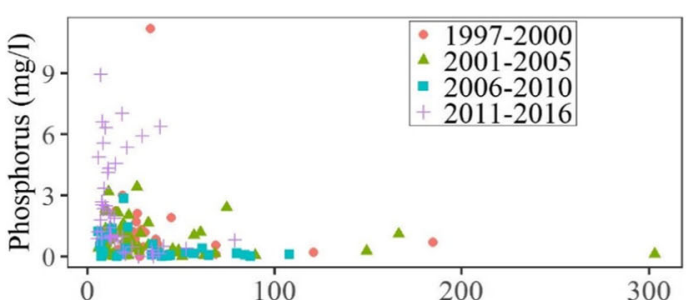

(a)

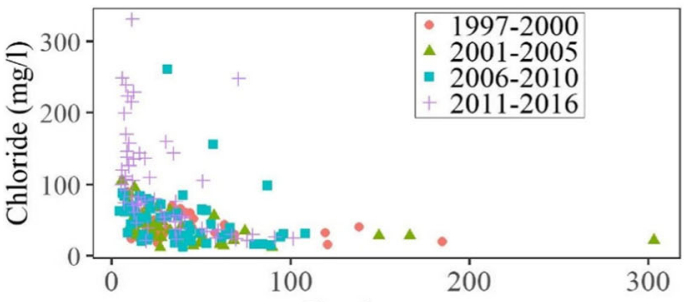

(b)

Flow in cumecs

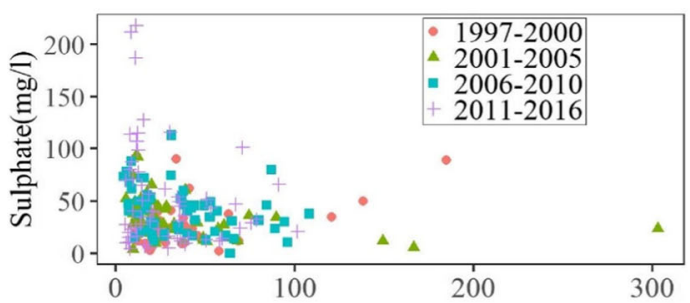

(c)

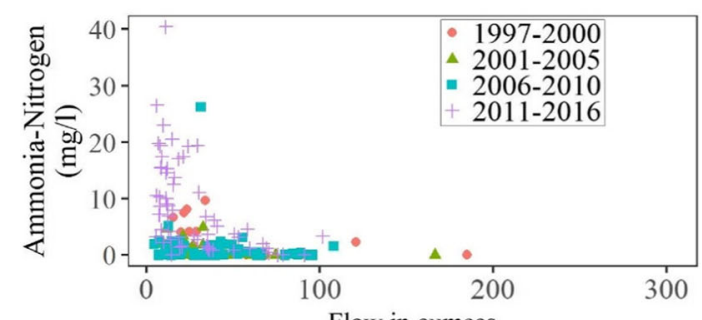

(d)

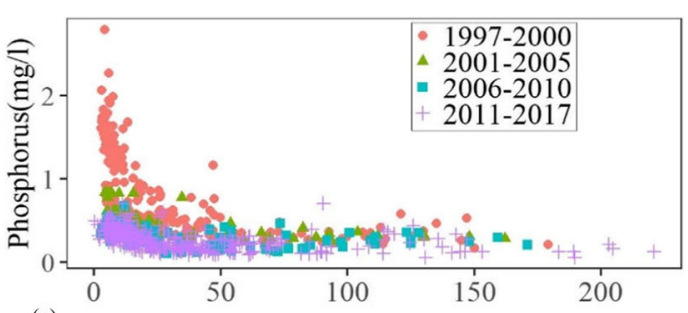

(e)

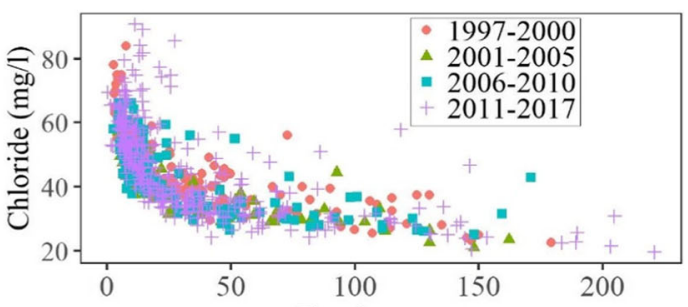

(f)

Flow in cumecs

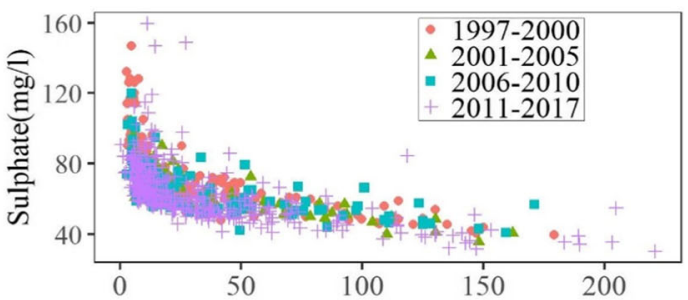

(g)

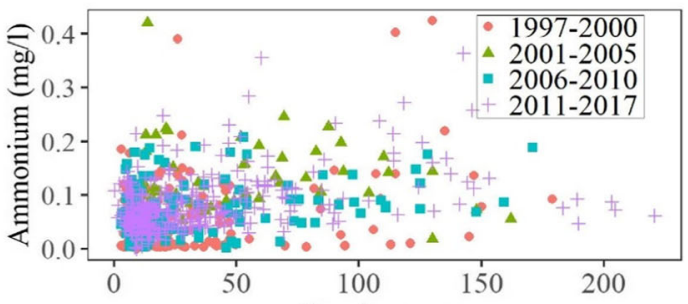

(h)

Flow in cumees

Fig. 6 Flow concentration relationship at Galeta in Hindon $(\mathbf{a}, \mathbf{b}, \mathbf{c}, \mathbf{d})$ and Wallingford in Thames $(\mathbf{e}, \mathbf{f}, \mathbf{g}, \mathbf{h})$

rainfall, it is observed that unlike Hindon basin, the Thames basin usually receives rainfall throughout the year and further maximum rainfall is received during winter, i.e. during November, December and January. Conversely, the Hindon basin receives most of its rain during summer monsoon, i.e. July, August and

Fig. 7 Mean areal rainfall

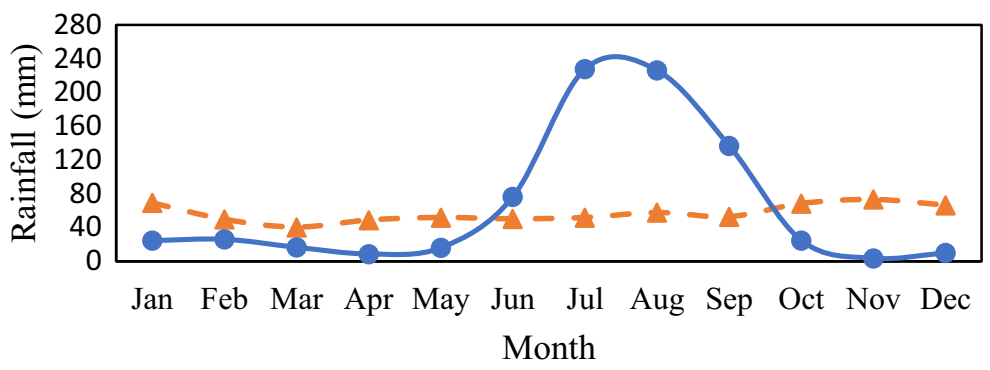

- - Thames (1990 to 2015)

— Hindon (1990 to 2015) 
Table 2 Comparative flow statistics

\begin{tabular}{lll}
\hline & Thames (daily data in cumecs) & Hindon (ten-daily data in cumecs) \\
\hline Period of record & $1970-2016$ & $1970-2016$ \\
Maximum flow (cumecs) & 531.00 & 683.486 \\
Minimum flow (cumecs) & 0.010 & 3.351 \\
Mean flow (cumecs) & 62.186 & 35.462 \\
$90 \%$ exceedence (Q90) & 8.040 & 10.090 \\
$70 \%$ exceedence (Q70) & 16.700 & 15.310 \\
$50 \%$ exceedence (Q50) & 36.400 & 21.625 \\
$30 \%$ exceedence (Q30) & 70.300 & 23.293 \\
$10 \%$ exceedence (Q10) & 155.00 & 72.103 \\
\hline
\end{tabular}

September. In the Thames basin, the porous Chalk aquifer gets continuously recharged even during the summer season, enough to maintain the base flow in the river. Conversely, the Hindon basin receives minimum rainfall or no rainfall during non-monsoon, which eventually tends to affect the base flow in the region.

\subsection{Role of Flow Characteristics on River Quality}

Base flow index (BFI) in a basin also determines the pollutant concentration in the river (Dutta et al., 2020). BFI is defined as the difference in area under the total runoff hydrograph and the base flow hydrograph. Shore et al. (2017) and Dutta et al. (2020) have also reported the role of increased flow in enhancement of dilution capacity of rivers due to increase in the base flow of the river. The Chalk aquifer in the Thames basin has a high BFI of 0.95 (Bloomfield et al., 2011), because of which the assimilating capacity of the river is very high, sufficient to maintain the variables like DO and BOD at a good level. Moreover, from the flow statistics (Table 2), it is observed that the Thames basin maintains a higher flow regime compared to the Hindon basin, and therefore the assimilative capacity of the river is very high and organic concentrations do not have much impact on
DO concentration whereby aquatic species are able to thrive in such an environment.

On the other hand, the Hindon basin is underlain by an alluvial aquifer as indicated by CGWB (2012). A study by Umar and Ahmed (2009), which was undertaken around the region of Krishni river and Yamuna river, revealed that although the region holds potential aquifers, the availability of ground water is at stake due to excessive pumping of ground water from the shallow aquifers, which eventually tends to affect the base flow characteristics. BFI for Hindon basin was analysed using the tendaily discharge data from 1970 to 2016, which is being monitored at the Galeta station. BFI was computed to be 0.41 for Hindon River. It is also observed that annual BFI fluctuates from 0.2 to 0.7 (Fig. 8) for the Hindon River system. However, seasonal BFI (Table 3) indicates that it is higher during winter and spring with 0.566 and 0.674 respectively and lowest during summer and autumn with 0.264 and 0.383 respectively. Higher BFI during winter and spring is basically due to lower amount of total discharge passing through the cross section and similarly, lower BFI during summer and autumn which is attributed to higher amounts of total discharge passing through the cross section. From the BFI analysed, it is understood that the contribution to river flow is very low in Hindon
Fig. 8 Annual BFI for the River Hindon at Galeta

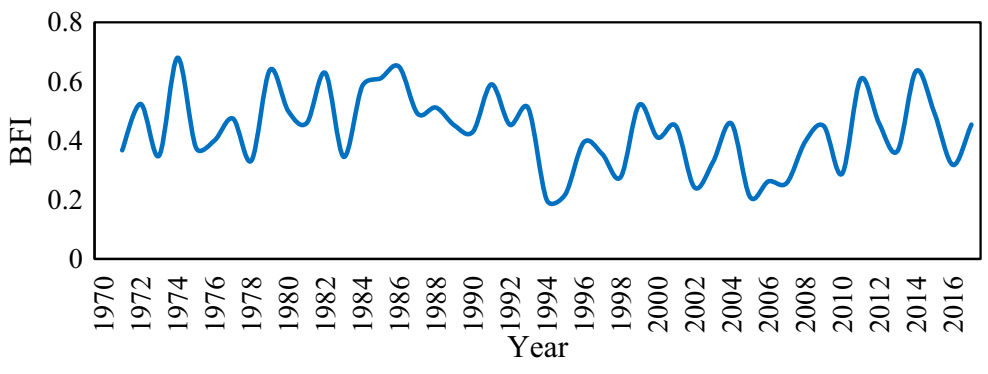


Table 3 Seasonal BFI for Hindon River

\begin{tabular}{ll}
\hline Period (1970-2016) & BFI \\
\hline Winter (Dec-Feb) & 0.566 \\
Spring (Mar-May) & 0.674 \\
Summer (Jun-Aug) & 0.264 \\
Autumn (Sep-Nov) & 0.383 \\
\hline
\end{tabular}

River during low flow period as compared to Thames River. Assimilative capacity is much less in Hindon basin owing to its lower flow regime, and further the situation is exacerbated by the disposal of raw and inadequately treated wastewater. Such situation has resulted in extremely low or even nil DO concentration in some stretches of the Hindon river. Such environment has disrupted the ecological functioning of the river leading to a hostile condition for aquatic life in this River.

\section{Restoration Measures and Impacts}

\subsection{Restoration Measures Adopted in River Thames} and Lessons for Hindon River

Thames River, once a severely polluted river in 1950s, is now a relatively clean and restored river owing primarily to the large number of primary, secondary and tertiary treatment facilities in the basin.

The huge difference in the water quality between two rivers is due to the management infrastructure that has been installed in the Thames basin, with about 357 major sewage treatment works (STWs) in the basin (Fig. 9), and other innumerable small treatment plants. Water Framework Directive (WFD) and European Union's Urban Wastewater Treatment Directive have been very instrumental in guiding the monitoring and treatment of river quality in Thames rendering the water to achieve the good ecological status. Most of the raw wastewater is intercepted by these STWs and only the treated water is released into the river. The tertiary treatment units in several STWs also help in stripping of nutrients from the sewage works. About 4.4 BLD of wastewater is being treated by these STWs (Thames Water, 2018). In terms of cost of treating waste and improving water quality, the local water company (Thames Water) has spent $£ 1$ billion per year on improving sewage treatment works. Besides, it has also been envisaged to spend $£ 3.8$ billion on constructing a new Tideway Tunnel along the Thames in London to intercept raw sewage inputs from combined sewer overflows to river Thames within London during extreme rainfall events (Thames Water, 2021). Dredging the river bed has also been taken up at few locations as

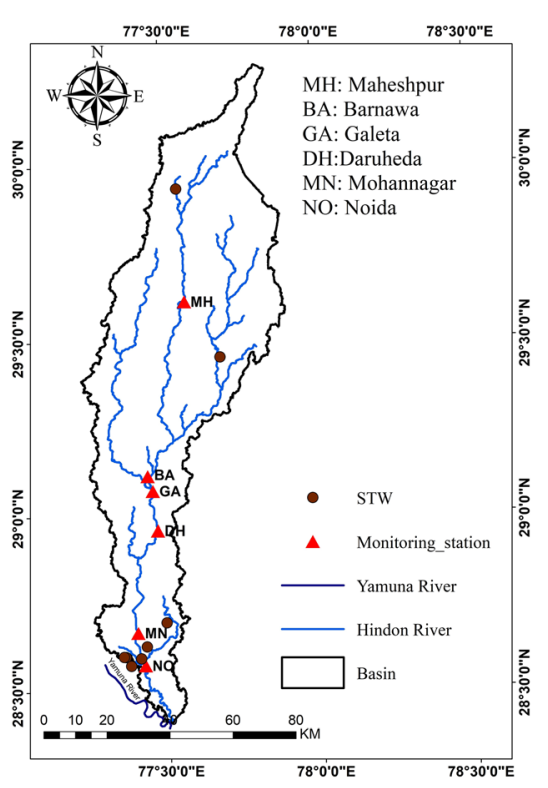

(a)

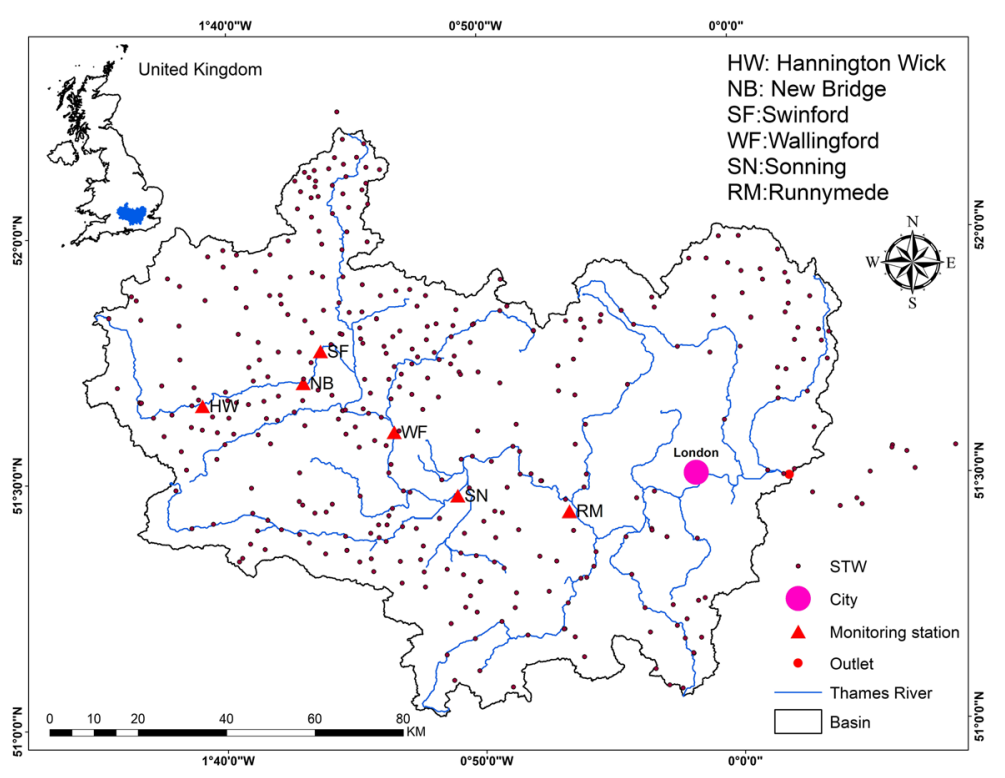

(b)

Fig. 9 STWs in a Hindon basin and $\mathbf{b}$ Thames basin 
Table 4 Sewage treatment plant in Hindon Basin

\begin{tabular}{|c|c|c|c|c|}
\hline Name of the STW & Total sewage generation (MLD) & Design capacity (MLD) & Type of STW & Location \\
\hline Saharanpur & 125 & 38 & UASB & \\
\hline Muzaffarnagar & 63 & 32.5 & $\mathrm{OP}$ & \\
\hline \multirow[t]{10}{*}{ Ghaziabad } & \multirow[t]{10}{*}{446} & 74 & SBR & Indrapuram \\
\hline & & 56 & SBR & Indrapuram \\
\hline & & 56 & UASBR & Indrapuram \\
\hline & & 56 & SBR & Dhudaheda, Vijay Nagar \\
\hline & & 70 & UASBR & Dhudaheda, Vijay Nagar \\
\hline & & 56 & SBR & Govindapurum \\
\hline & & 56 & & Bapudham \\
\hline & & 56 & & Morti \\
\hline & & 30 & & Sadulhabad, Loni \\
\hline & & 56 & UASB & \\
\hline \multirow[t]{2}{*}{ Noida } & 35 & 35 & UASB & G.B Nagar \\
\hline & 3.8 & 3.8 & & NTPC \\
\hline Greater Noida & $35-40$ & 137 & & \\
\hline Total & 712 & 812.3 & & \\
\hline
\end{tabular}

Source: CPCB, 2017

per need (Coulet \& Hunter, 2014; Environment Agency, 2009). There are also few artificial aquifer recharging locations within the basin, which further maintain the base flow. Another important aspect of restoring the Thames has been through construction and successful management of a series of wetlands, which tends to intercept the non-point sources before reaching the river. Further, there has been a continuous effort in empowering communities through community modelling strategies which help them identify possible spaces where wetlands can filter and retain pollutants.
Additionally, strong efforts on public awareness on pesticides, nitrates, hydrocarbons and solvents have also resulted in minimizing the inputs through agricultural activities. The water quality and ecological monitoring system has also been substantially strengthened over this period, resulting in addition of various emerging pollutants to the list of variables. Water supply and waste treatment activities have been privatized in Thames basin offering promising management and governance. To summarize, it is a sum total of all the above efforts and initiatives that have resulted in a perpetually

Table 5 Sewage and industrial load in the Hindon River

\begin{tabular}{|c|c|c|c|c|c|c|c|}
\hline \multirow[t]{2}{*}{ District/cities } & \multicolumn{2}{|c|}{ Industries } & \multicolumn{3}{|c|}{ Sewage discharge (MLD) } & \multirow[t]{2}{*}{ Total discharge (MLD) } & \multirow[t]{2}{*}{ Discharged into: } \\
\hline & Nos. & Treated effluent (MLD) & Treated & Untreated & Total & & \\
\hline Saharanpur & 45 & 17.89 & 38 & 82 & 120 & 137.89 & Hindon \\
\hline Muzaffarnagar & 45 & 37.30 & 0 & 73.84 & 73.84 & 111.14 & Hindon/kali \\
\hline Shamli & 5 & 2.35 & 0 & 10.5 & 10.5 & 12.85 & Krishni/Hindon \\
\hline Meerut & 4 & 1.86 & 0 & 10 & 10 & 11.86 & Hindon \\
\hline Baghpat & 1 & 0.5 & 0 & 0.1 & 0.1 & 0.6 & Hindon \\
\hline Ghaziabad & 353 & 18.49 & 186 & 195.203 & 381.203 & 399.693 & Hindon \\
\hline G.B Nagar & 20 & 50.945 & - & - & - & 50.94 & Hindon \\
\hline Total & 473 & $78.39^{*}$ & 224 & 371.643 & 595.643 & 724.973 & \\
\hline
\end{tabular}

Source: UPPCB, 2015. *Total discharge doesnot include for G.B Nagar, as information regarding amount of treated effluent is not available. 
Fig. 10 Treatment cost for various treatment technologies (ASP, activated sludge process; MBBR, moving bed biological reactor; SBR, sequential batch reactor; UASB, upflow anaerobic sludge blanket; MBR, membrane bio reactor; WSP, waste stabilization pond)

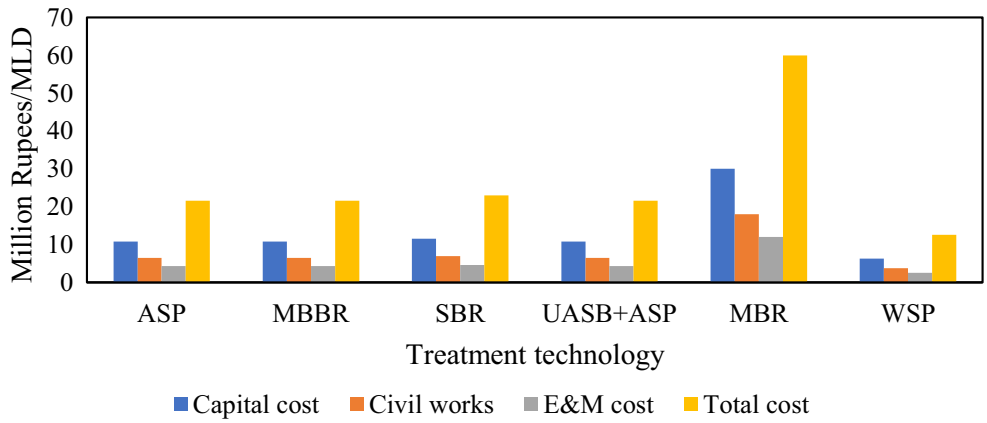

chemicals and manpower ranges from 1.7 to 2.49 million rupees per annum/MLD. This information may help in planning and establishment of various appropriate treatment technologies within the basin.

Restoration modelling studies in Hindon River by Sharma and Joshi (2021) showed that sediment oxygen demand (SOD) had severe impact on the DO level of the Hindon River; therefore, dredging along the river can perhaps substantially improve the DO levels in the river. The study also showed that dredging along the river might be less expensive owing to availability of affordable labour and equipment as opposed to that of Thames where it costed $£ 66.67$ per cubic metre including the cost of disposal and treatment of disposed material and $£ 11.26$ per cubic metre in Thorpe River Green, Norwich, excluding the disposal and treatment. Further, the Hindon basin having an agricultural cover of $87.16 \%$, the probability of non-point leaching of nutrients like phosphorus into the river system seems enormous and until a judicious use scenario along with proper basin treatment through best management practices (BMP) is not enforced by the regulatory authorities, the river will continue to degrade. Flow in the river may also be augmented from the Upper Ganga Canal in the near vicinity to increase the dilution and reduce the concentration of pollutants in the river as suggested by Babbar et al. (2009) and Sharma et al. (2014).

The infrastructure invested in the treatment of wastewater in Thames as the major step along with a plethora of other initiatives as discussed above indeed offers a learning lesson for the management of the Hindon River to achieve the desired restoration goals. Furthermore, various other actions like construction and management of wetlands, promoting artificial recharge, surface flow augmentation, structural measures, in situ remediation and aeration measures and bottom dredging also seem to be other desirable options for the Hindon River system. 
Last but not the least, strengthening of monitoring setup and enhancement of public awareness on various issues should need much more attention than as at present.

\subsection{Initiatives of Government of India (GoI) Towards Restoration of River Quality in Ganga Basin}

It may also be worthwhile to note that Govt. of India has already initiated Namami Gange Program (NGP) under National Mission for Clean Ganga (NMCG), wherein a host of measures for the restoration of river Ganga primarily and various other important tributaries within Ganga-Yamuna river system, which includes Hindon River, have been taken up to varying extent. Nevertheless, the measures, few of which are described below, do clearly indicate the priorities of the GoI in the context of river restoration (Simon \& Joshi, 2021) as they provide lot of hope for future. Projects have already been sanctioned for increasing the sewage treatment capacity to 3314 MLD, and these projects are at various stages of implementation (Dutta et al., 2020; NMCG, 2020), The projects undertaken so far would take care of all the necessary interventions for all five states: Uttarakhand, Uttar Pradesh, Bihar, Jharkhand and West Bengal in relation to the necessity for sewage treatment on the main stem of the Ganga River until 2035.

Regarding the industrial effluents, the actions have been suggested to focus on source control using effective measures like wider use of CETPs, serious considerations in effective enforcement, regulation and even future socio-economic changes in long-term industrial expansion while utilizing advanced eco-friendly technologies (Hoffman et al., 2017). State and central government agencies have been advised to enforce the "polluter pays" concept, get harsher on violating industries, and conduct periodic and surprise audits for compliance verification against specified pollution standards, by third party technical organizations.

Solid waste management (SWM) is a significant part of NGP, and Ganga River would not be fully clean unless the issue of SWM is addressed promptly. It is the sole responsibility of the State Governments/Urban Local Bodies and falls within the directive of the Ministry of Housing and Urban Affairs (MoHUA) at the Central level. The SWM projects being carried out by MoHUA are in addition to several other initiatives undertaken by NMCG, such as river surface cleaning by trash skimmers in few Ganga towns and Ghat Cleaning in Varanasi. In addition, MoHUA has encouraged these states to install bar screens on drains falling into the River Ganga to avert the flowing solid waste into the river and to segregate waste at source (PIB, 2018b).

River basin management is being adopted as a holistic approach to restore the Ganga river system and revive its ecological health, taking due account of the problem of competing water use in the river basin. It, along with other factors, also includes Environmental flow management (Tare et al., 2013), comprehensive quality assessment periodically (PIB, 2018a) and controlled groundwater extraction (CGWA, 2018).

Afforestation and bio-diversity conservation interventions have also been taken up with the objective to promote community-driven sustainable land and ecosystem management of the riverscape, while improving and maintaining the forest/vegetation cover in the buffer zone along the course of river Ganga and its tributaries, and protection and conservation of the representative biodiversity of the Ganga riverscape (WWF et al., 2019). NMCG is also in the process of evaluating and promoting in situ bioremediation technology, which is the process of treating polluted wastewater at the site itself using microbial/phytoremediation technologies with no major structural modification of the site (CPCB, 2020).

\section{Conclusions}

The present study was undertaken with an aim to undertake a holistic assessment of the pollution scenario as well as to explore the appropriate measures for restoring the severely polluted Hindon River in India in reference to the Thames River, which has successfully undergone continued restoration over several years.

From the water quality analysis of the Thames and Hindon, it was observed that Thames basin exhibits better water quality condition with DO greater than 8 $\mathrm{mg} / \mathrm{l}$ and BOD less than $7.5 \mathrm{mg} / \mathrm{l}$. Further, pollution due to nutrients such as phosphorus and ammonia-nitrogen is also much lower, with phosphorus ranging from 0.1 to $0.6 \mathrm{mg} \mathrm{P} / 1$ at all the monitoring stations. In sharp contrast, the Hindon basin suffers from a severe pollution with DO less than $5 \mathrm{mg} / \mathrm{l}$ and on an average BOD is greater than $15 \mathrm{mg} / \mathrm{l}$ at all the monitoring stations. Nutrients like phosphorus are in the range of 2-6 mg $\mathrm{P} / \mathrm{l}$ at most of the monitoring stations. Further, it was also observed that water quality in the Hindon River has significantly deteriorated during the years 2013-2016, 
which may be due to the uncontrolled discharge of municipal and industrial waste and establishment of multiple small-scale industries within the region. It is also evident from the flow concentration relationship that a majority of pollutant load in Hindon basin comes from point sources which are apparently due to the discharge of municipal and industrial wastes.

Although the Thames basin receives less rainfall than the Hindon, it typically receives rainfall uniformly distributed throughout the year, which makes the basin much wetter relatively. Due to such minimal but continuous rainfall, it can maintain the aquifer naturally throughout the year, which ultimately increases the base flow and thus provides the environmental flows required to maintain aquatic life. The low BFI of the Hindon basin results in low flows during the long dry period, and the point-source pollutants from the urban and industrial sources are not diluted by the river. This necessitates the need of direct surface flow augmentation as well as promoting groundwater recharge measures in the Hindon basin to improve the base flow.

From the restoration perspective, it emerges that besides the unique climatic and hydrological processes, strategic and innovative management practices and investment in the infrastructure in the Thames basin have been a major factor that is able to maintain the pollution to a significantly lower level compared to the Hindon and, as a result, exhibits better water quality conditions. In particular, the investment made in the wastewater treatment technologies, alongside unique basin level initiatives, regulation of industry and artificial recharge measures for the Thames are indeed learning lessons for the Hindon river system, which have shown how to cope with increase in urbanization and industrialization. In recent decades, one more factor has been the introduction of the European Union's Urban Wastewater Treatment Directive (EEC, 1991), which enforced strict phosphorus consents on all STW serving over 100,000 people, and the Water Framework Directive (WFD), which sets targets for all member states to achieve good ecological status in their rivers in the coming decades. This has resulted in step reductions in phosphorus concentrations of $>80 \%$ since the late 1990s (Bowes et al., 2012; Kinniburgh \& Barnett, 2010; Neal et al., 2010). This transformation in chemical and ecological status of the Thames river offers a blueprint for how grossly polluted rivers in rapidly developing regions, such as the Hindon River, can be improved. In addition to the consolidated restoration measures as adopted in Thames
River, steps like surface flow augmentation, developing stream wetland complexes at few locations along the river flow path and planning appropriate structural in situ measures in the river to increase turbulence may also be adopted.

\section{Discussion: the Way Forward}

Based on the results achieved in the Thames basin as well as the proposed initiatives of Govt. of India, it is well understood that prioritization of various above stated restoration approaches would be the key to improve the condition in the Hindon basin based on shortterm and long-term restoration goals and estimated time for those. Needless to say, an efficient collection and interception of wastewater of all types followed by construction of advanced STWs including tertiary treatment for nutrient removal and upgradation of existing STWs would need to be the first step. It may be well understood, however, that such restorative measures cannot be expected to fall in place and achieve the restorative goals within a short period of time in a realistic sense. The immediate investment, depending upon the treatment technology, could be around 12.660 million rupees/MLD in capital cost for the establishment of the STWs in India while the additional cost for operation and maintenance may account for about 1.72.49 million rupees per annum/MLD. These estimates exclude the cost of developing infrastructure for collection and interception of wastewater. Selective dredging of degraded riverbed in critical stretches needs to be done for reducing the sediment oxygen demand of the river. Although the cost of dredging could not be figured out for the Hindon river system, dredging works in Thames have shown that cost may vary from $£ 11.26$ to $£ 66.67$ per cubic metre depending upon cost of disposal and treatment of dredged material. It is, however, envisaged that the cost of dredging in India will be much lower owing to the availability of affordable labour and equipment. River flow augmentation, solid waste management, catchment treatment and wide-scale promotion of artificial recharge as well as reducing nonjudicious extraction of groundwater in the catchment (especially in the agricultural sector) are yet other long-term measures, which would need efficient interagency coordination and allocation of funds. Strengthening of monitoring setup would also be a long-term investment needing installation of a few continuous 
automatic stations along with addition of emerging parameters in the list of analyses calling for upgrading of the testing infrastructure. Criticality of the river stretches may be yet other consideration wherein few additional short-term technical restoration approaches may be visualized, e.g. in situ innovative remediation (including phyto-bio-remediation), structural measures and construction of river-wetland complexes, which may be handled at a smaller administrative scale, and may deliver positive results within a shorter time frame. Involvement of stakeholders in all stages of restoration would need very effective public communication and media-based outreach on an ongoing basis.
It is however expected that as NMCG has already initiated actions towards Ganga River restoration and the government is quite determined to bring back rivers to life, investments may not be a big problem in the times to come. Nevertheless, viewed on a large canvas, a river basin-based management approach, better implementation of the available regulations and policy interventions in the form of bringing in TMDL (total maximum daily load)-based standards rather than just concentration-based standards would be desirable to be adopted countrywide to make any restoration exercise a success.

\section{Appendix}

Table 6 Friedman rank sum test (among stations)

\begin{tabular}{lllll}
\hline Variable & chi sq. & df & $p$-value & Remarks \\
\hline DO & 16.571 & 5 & 0.00539 & Significant $(p<0.05)$ \\
BOD & 19.571 & 5 & 0.0015 & Significant $(p<0.05)$ \\
COD & 14.8 & 5 & 0.00514 & Significant $(p<0.05)$ \\
Water temperature & 13 & 5 & 0.02338 & Significant $(p<0.05)$ \\
pH & 9.8571 & 5 & 0.07939 & Not significant $(p>0.05)$ \\
Phosphorus & 16.143 & 5 & 0.00645 & Significant $(p<0.05)$ \\
T.coliform & 19 & 5 & 0.00192 & Significant $(p<0.05)$ \\
Chlorides & 19.571 & 5 & 0.0015 & Significant $(p<0.05)$ \\
TDS & 17 & 5 & 0.0045 & Significant $(p<0.05)$ \\
\hline
\end{tabular}

Table 7 Friedman rank sum test (among seasons)

\begin{tabular}{lcccc}
\hline Variable & chi sq. & df & $p$-value & Remarks \\
\hline DO & 13.2 & 3 & 0.0042 & Significant $(p<0.05)$ \\
BOD & 15.2 & 3 & 0.0016 & Significant $(p<0.05)$ \\
COD & 5.16 & 3 & 0.1604 & Not significant $(p>0.05)$ \\
Water temperature & 16.4 & 3 & 0.0009 & Significant $(p<0.05)$ \\
pH & 6.2 & 3 & 0.1023 & Not significant $(p>0.05)$ \\
Phosphorus & 3.4 & 3 & 0.334 & Not significant $(p>0.05)$ \\
T.coliform & 11 & 3 & 0.01173 & Significant $(p<0.05)$ \\
Chlorides & 11.4 & 3 & 0.0097 & Significant $(p<0.05)$ \\
TDS & 9.8 & 3 & 0.02034 & Significant $(p<0.05)$ \\
\hline
\end{tabular}


Table 8 Interaction analysis for BOD

\begin{tabular}{llllr}
\hline BOD & Value & Df & Chisq & Pr(>Chisq) \\
\hline Winter-Autumn : MH-MN & 338.13 & 1 & 12.79 & 0.02893 \\
Spring-Autumn : MH-MN & 395.73 & 1 & 17.35 & 0.00267 \\
Winter-Autumn : MH-NO & 351.31 & 1 & 13.81 & 0.01703 \\
Spring-Autumn : MH-NO & 326.29 & 1 & 11.80 & 0.04743 \\
Spring-Summer : GA-DH & 334.22 & 1 & 12.38 & 0.03561 \\
Spring-Autumn : GA-DH & 459.20 & 1 & 23.37 & 0.00012 \\
Winter-Spring : GA-MN & -324.65 & 1 & 12.16 & 0.03952 \\
Spring-Summer : GA-MN & 427.61 & 1 & 20.26 & 0.00059 \\
Spring-Autumn : GA-MN & 544.23 & 1 & 32.82 & $9.1 \mathrm{E}-07$ \\
Spring-Summer : GA-NO & 363.48 & 1 & 14.64 & 0.01106 \\
Spring-Autumn : GA-NO & 474.79 & 1 & 24.98 & $5.2 \mathrm{E}-05$ \\
\hline
\end{tabular}

Table 9 Interaction for DO

\begin{tabular}{|c|c|c|c|c|c|}
\hline DO & Value & Df & Sum of Sq & $\mathrm{F}$ & $\operatorname{Pr}(>\mathrm{F})$ \\
\hline DH-MN : Winter-Autumn & 375.564 & 1 & $1,760,284$ & 15.0813 & 0.00979 \\
\hline MH-GA : Spring-Summer & 345.873 & 1 & $1,479,035$ & 12.6716 & 0.03398 \\
\hline MH-GA : Spring-Autumn & 357.643 & 1 & $1,581,418$ & 13.5488 & 0.02163 \\
\hline
\end{tabular}

Table 10 Interaction for chlorides

\begin{tabular}{|c|c|c|c|c|c|}
\hline Chloride & Value & Df & Sum of Sq & $\mathrm{F}$ & $\operatorname{Pr}(>\mathrm{F})$ \\
\hline Winter-Summer : MH-BA & 322.032 & 1 & $1,294,234$ & 12.4621 & 0.02761 \\
\hline Winter-Autumn : MH-BA & 447.449 & 1 & $2,498,625$ & 24.0591 & $8.4 \mathrm{E}-05$ \\
\hline Spring-Summer : MH-BA & 385.588 & 1 & $1,838,204$ & 17.6999 & 0.00198 \\
\hline Spring-Autumn : MH-BA & 511.005 & 1 & $3,228,467$ & 31.0866 & $2.6 \mathrm{E}-06$ \\
\hline Winter-Autumn : MH-GA & 318.162 & 1 & $1,263,313$ & 12.1643 & 0.03183 \\
\hline Spring-Summer : MH-GA & 343.635 & 1 & $1,459,958$ & 14.0578 & 0.01246 \\
\hline Spring-Autumn : MH-GA & 415.114 & 1 & $2,130,497$ & 20.5144 & 0.00048 \\
\hline Winter-Autumn : MH-DH & 447.545 & 1 & $2,499,699$ & 24.0694 & $8.4 \mathrm{E}-05$ \\
\hline Spring-Summer : MH-DH & 385.82 & 1 & $1,840,413$ & 17.7212 & 0.00198 \\
\hline Spring-Autumn : MH-DH & 530.799 & 1 & $3,483,425$ & 33.5416 & 7.9E-07 \\
\hline Winter-Summer : MH-MN & 333.663 & 1 & $1,389,415$ & 13.3786 & 0.01755 \\
\hline Winter-Autumn : MH-MN & 470.788 & 1 & $2,766,089$ & 26.6344 & $2.4 \mathrm{E}-05$ \\
\hline Spring-Summer : MH-MN & 350.728 & 1 & $1,520,852$ & 14.6442 & 0.0093 \\
\hline Spring-Autumn : MH-MN & 487.853 & 1 & $2,942,552$ & 28.3336 & $1 \mathrm{E}-05$ \\
\hline Winter-Summer : BA-NO & -350.36 & 1 & $1,531,980$ & 14.7513 & 0.00892 \\
\hline Winter-Autumn : BA-NO & -441.28 & 1 & $2,430,211$ & 23.4003 & 0.00011 \\
\hline Spring-Summer : BA-NO & -462.47 & 1 & $2,644,365$ & 25.4624 & $4.2 \mathrm{E}-05$ \\
\hline
\end{tabular}


Table 10 (continued)

\begin{tabular}{|c|c|c|c|c|c|}
\hline Chloride & Value & Df & Sum of Sq & $\mathrm{F}$ & $\operatorname{Pr}(>\mathrm{F})$ \\
\hline Spring-Autumn : BA-NO & -553.39 & 1 & $3,786,259$ & 36.4576 & $1.9 \mathrm{E}-07$ \\
\hline Winter-Autumn : GA-NO & -311.99 & 1 & $1,214,803$ & 11.6972 & 0.04015 \\
\hline Spring-Summer : GA-NO & -420.52 & 1 & $2,186,358$ & 21.0523 & 0.00037 \\
\hline Spring-Autumn : GA-NO & -457.5 & 1 & $2,587,786$ & 24.9176 & $5.5 \mathrm{E}-05$ \\
\hline Winter-Summer : DH-NO & -330.9 & 1 & $1,366,474$ & 13.1577 & 0.01941 \\
\hline Winter-Autumn : DH-NO & -441.38 & 1 & $2,431,270$ & 23.4105 & 0.00011 \\
\hline Spring-Summer : DH-NO & -462.71 & 1 & $2,647,014$ & 25.4879 & 4.2E-05 \\
\hline Spring-Autumn : DH-NO & -573.19 & 1 & $4,061,963$ & 39.1123 & $5 \mathrm{E}-08$ \\
\hline Winter-Summer : MN-NO & -362 & 1 & $1,635,386$ & 15.747 & 0.00538 \\
\hline Winter-Autumn : MN-NO & -464.62 & 1 & $2,694,082$ & 25.9411 & $3.4 \mathrm{E}-05$ \\
\hline Spring-Summer : MN-NO & -427.61 & 1 & $2,260,737$ & 21.7684 & 0.00026 \\
\hline Spring-Autumn : MN-NO & -530.24 & 1 & $3,476,078$ & 33.4709 & 8.1E-07 \\
\hline
\end{tabular}

Table 11 Interaction for phosphorus

\begin{tabular}{lcccrr}
\hline Phosphorus & Value & Df & Sum of Sq & F & Pr( $>$ F $)$ \\
\hline Winter-Spring : MH-MN & 331.646 & 1 & $1,415,975.2$ & 12.5053 & 0.03711 \\
Winter-Summer : MH-MN & 344.933 & 1 & $1,484,852.5$ & 13.1136 & 0.02721 \\
Winter-Autumn : MH-MN & 521.12 & 1 & $3,389,146.9$ & 29.9316 & $4.9 \mathrm{E}-06$ \\
\hline
\end{tabular}

\section{References}

Abdi, R., Endreny, T., \& Nowak, D. (2020). A model to integrate urban river thermal cooling in river restoration. Journal of Environmental Management, 258, 110023. https://doi. org/10.1016/j.jenvman.2019.110023.

Babbar, R., Arya, D. S., \& Joshi, H. (2009). A proposed decision support system for river water quality management in India. Journal of Decision Systems, 18(4), 411-427. https://doi. org/10.3166/jds.18.411-427.

Bernhardt, E. S., \& Palmer, M. A. (2011). River restoration: The fuzzy logic of repairing reaches to reverse catchment scale degradation. Ecological Applications, 21(6), 1926-1931.

Bernhardt, E. S., Palmer, M. A., Allan, J. D., Alexander, G., Barnas, K., Brooks, S., \& Sudduth, E. (2005). Synthesizing U.S. river restoration efforts. Science, 308(April), 636-637. https://doi.org/10.1126/science.1109769.

Bloomfield, J. P., Bricker, S. H., \& Newell, A. J. (2011). Some relationships between lithology, basin form and hydrology: A case study from the Thames basin, UK. Hydrological Processes, 25(16), 2518-2530. https://doi.org/10.1002 hyp.8024.

Bowes, M. J., Smith, J. T., Jarvie, H. P., \& Neal, C. (2008). Modelling of phosphorus inputs to rivers from diffuse and point sources. Science of the Total Environment, 395(2-3), 125-138. https://doi.org/10.1016/j.scitotenv.2008.01.054.

Bowes, M. J., Ings, N. L., McCall, S. J., Warwick, A., Barrett, C., Wickham, H. D., \& Singer, A. C. (2012). Nutrient and light limitation of periphyton in the River Thames: Implications for catchment management. Science of the Total Environment, 434, 201-212. https://doi.org/10.1016/j. scitotenv.2011.09.082.

Bowes, M. J., Armstrong, L. K., Harman, S. A., Wickham, H. D., Nicholls, D. J. E., Scarlett, P. M., \& Gifford, C. (2018). Weekly water quality monitoring data for the River Thames ( UK ) and its major tributaries (2009-2013): The Thames Initiative research platform. Earth Syst.Sci.Data, 10, 16371653.

Centre of Ecology and Hydrology. (2016). National River Flow Archive: Station mean flow data. Retrieved December 19, 2017 , from ht t p:// n rfa.ce h. a c. uk/data/station/meanflow/42003

CGWA (Central Ground water Authority). (2018). Notification: Guideline to regulate and control ground water extraction. Ministry of Water Resource.

CGWB. (2012). Aquifer systems of India. Government of India.

Coulet, W., \& Hunter, T. (2014). Thorpe River Green Dredging Pilot. Thorpe Saint Andrew. 
CPCB (Central Pollution Control Board). (2017). Restoration of polluted river stretches: Concept and plan. PariveshBhawan, East Arjun Nagar, Delhi-110032.

CPCB (Central Pollution Control Board) (2020). In-situ bioremediation techniques for waste water treatment-Compliance report in O.A. No. 06/2012, Order dated 03.01.2020.

Duel, H., Baptist, M. ., Geerling, G. ., Smits, A. J. \& Van Alphen, J. (2002). Cyclic floodplain rejuvenation as a strategy for both flood protection and enhancement of the biodiversity of the river Rhine. In 4th Ecohydraulics (pp. 1-24).

Dutta, V., Dubey, D., \& Kumar, S. (2020). Cleaning the River Ganga: Impact of lockdown on water quality and future implications on river rejuvenation strategies. Science of the Total Environment, 743, 140756. https://doi.org/10.1016/j. scitotenv.2020.140756.

EEC (1991). Council directive concerning urban waste-water treatment. Official Journal of the European Communities. Brussels, Belgium. https://doi.org/http://eur-lex.europa. eu/legal-content/en/ALL/?uri=CELEX:31991 L0271

Environment Agency. (2009). River basin management plan Thames River basin district. Bristol.

Hillier, J., \& Bell, S. (2010). The "Genius of Place": Mitigating stench in the new palace of Westminster before the Great Stink. The London Journal, 35(1), 22-38. https://doi. org/10.1179/174963210X12598738033378.

E. Hoffman, J. Lyons, J. Boxall, C. Robertson, C. B. Lake, and T. R. Walker, (2017).Spatiotemporal assessment (quarter century) of pulp mill metal(loid) contaminated sediment to inform remediation decisions, Environ. Monit. Assess., 189 (6). doi:https://doi.org/10.1007/s10661-017-5952-0

Jain, C., \& Sharma, M. (2001). Distribution of trace metals in the Hindon River system, India. Journal of Hydrology, 253(14), 81-90. https://doi.org/10.1016/S0022-1694(01)00484-X.

Janhit Foundation. (2007). Hindon River : Gasping for Breath. Janhit Foundation.

Johnson, M. F., Thorne, C. R., Castro, J. M., Kondolf, G. M., Mazzacano, C. S., Rood, S. B., \& Westbrook, C. (2020). Biomic river restoration: A new focus for river management. River Research and Applications, 36(1), 3-12. https://doi. org/10.1002/rra.3529.

Kinniburgh, J. H., \& Barnett, M. (2010). Orthophosphate concentrations in the River Thames: Reductions in the past decade. Water and Environment Journal, 24(2), 107-115. https://doi. org/10.1111/j.1747-6593.2008.00161.x.

Kumar, A., Mishra, S., Taxak, A. K., Pandey, R., \& Yu, Z. G. (2020). Nature rejuvenation: Long-term (1989-2016) vs short-term memory approach based appraisal of water quality of the upper part of Ganga River, India. Environmental Technology and Innovation, 20, 101164. https://doi. org/10.1016/j.eti.2020.101164.

Loucks, D. P., \& Avakyan, A. (1998). Restoration of degraded rivers: challenges, Issues and experiences. Kluwer Academic Publishers.

Marsh, T. J., \& Hannaford, J. (2008). UK Hydrometric Register. Ecology. Centre of Ecology and Hydrology. Retrieved from http://nora.nerc.ac.uk/3093/1/HydrometricRegister_Final_ WithCovers.pdf\%0A http://www.ceh.ac. uk/products/publications/documents/HydrometricRegister Final_WithCovers.pdf

Mondal, S., \& Patel, P. P. (2018). Examining the utility of river restoration approaches for flood mitigation and channel stability enhancement: a recent review. Environmental Earth Sciences, 77(195). https://doi.org/10.1007/s12665018-7381-y

Morandi, B., Kail, J., Toedter, A., Wolter, C., \& Piegay, H. (2017). Diverse approaches to implement and monitor river restoration: A comparative perspective in France and Germany. Environmental Management, 60, 931-946. https://doi. org/10.1007/s00267-017-0923-3.

National Institute of Hydrology. (1999). Hydro-chemical studies of Hindon River , CS(AR)-21/98-99. National Institute of Hydrology, .

Neal, C., Jarvie, H. P., Williams, R., Love, A., Neal, M., Wickham, H., \& Armstrong, L. (2010). Declines in phosphorus concentration in the upper River Thames (UK): Links to sewage effluent cleanup and extended end-member mixing analysis. Science of the Total Environment, 408(6), 13151330. https://doi.org/10.1016/j.scitotenv.2009.10.055.

NMCG. (2020). Leading river rejuvenation a case of Namami Gange. National Mission for Clean Ganga. Department of Water Resources.

Palmer, M. A., Bernhardt, E. S., Allan, J. D., Lake, P. S., Alexander, G., Brooks, S., \& Sudduth, E. (2005). Standards for ecologically successful river restoration. Journal of Applied Ecology, 42(2), 208-217. https://doi.org/10.1111 j.1365-2664.2005.01004.x.

Peterson, B. G., Carl, P., Boudt, K., Bennet, R., Ulrich, J., Zivot, E., Wuertz, D. (2018). PerformanceAnalytics: Econometric tools for performance and risk analysis. $R$ topics documented.

PIB (Press Information Bureau). (2018a). Achievements of Ministry of Water Resources. River Development and Ganga Rejuvenation during, 2018 Retrieved April 14, 2021, from https://pibindia.wordpress.com/2018/12/19 /achievements-of-ministry-of-water-resources-riverdevelopment-and-ganga-rejuvenation-during-2018/.

PIB (Press Information Bureau). (2018b). Solid Waste Management Projects in 97 Ganga Towns. Retrieved April 14, 2021, from https://pib.gov.in/Pressreleaseshare. aspx?PRID=1541298

Rai, R. K., Upadhyay, A., \& Trivedi, R. C. (2010). Yamuna Action Plan: Phase II. National River Conservation Directorate.

Ranjan, A., \& Singhal, M. K. (2014). Water quality assessment and conservation strategies for the upper stretch of Hindon river - a tributary of Yamuna, India. International Journal of Water, 8(3), 330-342. https://doi.org/10.1504 /IJW.2014.064224.

Rizvi, N., Katyal, D., \& Joshi, V. (2015). Assessment of water quality of Hindon River in Ghaziabad and Noida, India by using multivariate statistical methods. Journal of Global Ecology and Environment, 3(September), 80-90.

Sharma, V., \& Joshi, H. (2021) (in press). Restoration scenarion analysis of Hindon river in India using Water quality model, WASP8. International Journal of Environment and Health.

Sharma, M. K., Jain, C. K., \& Singh, O. (2014). Characterization of point sources and water quality assessment of River Hindon using water quality index. Journal of Indian Water Resources Society, 34(1), 53-64.

Shore, M., Murphy, S., Mellander, P. E., Shortle, G., Melland, A. R., Crockford, L., \& Jordan, P. (2017). Influence of stormflow and baseflow phosphorus pressures on stream ecology in agricultural catchments. Science of the Total 
Environment, 590-591, 469-483. https://doi.org/10.1016/j. scitotenv.2017.02.100.

Simon, M \& Joshi, H. (2021) (In press). Story of the Ganga River: Its pollution and rejuvenation, in A. Mukherjee (Ed), Riverine systems: Understanding the hydrological, hydrosocial and hydroheritage connections, Springer \& Capital.

Speed, R., Li, Y., Tickner, D., Huojian, H., Naiman, R. J., Jianting, C., \& Yui, W. (2016). River restoration : A strategic approach to planning and management. UNESCO.

Stoffers, T., Collas, F. P. L., Buijse, A. D., Geerling, G. W., Jans, L. H., van Kessel, N., \& Nagelkerke, L. A. J. (2021). 30 years of large river restoration: How long do restored floodplain channels remain suitable for targeted rheophilic fishes in the lower river Rhine? Science of the Total Environment, 755, 142931. https://doi.org/10.1016/j.scitotenv.2020.142931.

Suthar, S., Sharma, J., Chabukdhara, M., \& Nema, A. K. (2010). Water quality assessment of river Hindon at Ghaziabad, India: Impact of industrial and urban wastewater. Environmental Monitoring and Assessment, 165(1-4), 103112. https://doi.org/10.1007/s10661-009-0930-9.

Szalkiewicz, E., Jusik, S., \& Grygoruk, M. (2018). Status of and perspectives on river restoration in Europe: 310,000 Euros per hectare of restored river. Sustainability, 10(1). https://doi. org/10.3390/su10010129.

Szałkiewicz, E., Sucholas, J., \& Grygoruk, M. (2020). Feeding the future with the past: Incorporating local ecological knowledge in river restoration. Resources, 9(47), 1-15. https://doi. org/10.3390/RESOURCES9040047.

Tare, V., Philip, L., Kazmi, A. ., Bose, P., Nema, A. ., Mittal, A., Hait, S. (2010). Sewage treatment in Class I towns: Recommendations and guidelines : Report Code: 003 GBP_IIT_EQP_S\&R_O2_Ver 1_Dec 2010. Consortium of Indian Institute of Technology (IIT).

Tare, V., Philip, L., Kazmi, A. ., Bose, P., Nema, A. ., Mittal, A. ., Hait, S. (2013). Ganga River Basin Environment Management Plan : Interim Report. Consortium of 7 Indian Institute of Technology's (IITs), Government of India.

Thames Water. (2018). Corporate responsibility \& sustainability. United Kingdom.

Thames Water. (2021). Thames Tideway Tunnel. Retrieved April 4, 2021, from https://www.thameswater.co.uk/aboutus/investing-in-our-region/thames-tideway-tunnel
Theodoropoulos, C., Stamou, A., Varakas, L., Papadaki, C., Dimitriou, E., Skoulikidis, N., \& Kalogianni, E. (2020). River restoration is prone to failure unless pre-optimised within a mechanistic ecological framework: Insights from a model-based case study. Water Research, 173, 115550. https://doi.org/10.1016/j.watres.2020.115550.

Umar, R., \& Ahmed, I. (2009). Sustainability of a shallow aquifer in Yamuna-Krishni interstream region, Western Uttar Pradesh, India: A quantitative assessment. In Trends and Sustainability of Ground water in Highly Stressed Aquifers, Proc. of Symposium JS.2 at the Joint IAHS \& IAH Convention (pp. 103-112). Hyderabad, India: IAHS. Retrieved from http://iahs.info/redbooks/a329/IAHS Publ 329/14 103-112 329-35 4245_JS2_1 umar.pdf

UPPCB (Uttarpradesh Pollution Control Board). (2015). Action plan for restoration of polluted stretch of River Hindon from District Saharanpur to District Ghaziabad. Gomtinagar.

Wickham, H. (2016). ggplot2: Elegant graphics for data analysis. Springer-Verlag. https://doi.org/10.1093 /bioinformatics/btr406.

Wobbrock, J. O., Findlater, L., Gergle, D., \& Higgins, J. J. (2011). The aligned rank transform for nonparametric factorial analyses using only ANOVA procedures. In In CHI 2011 - 29th Annual CHI Conference on Human Factors in Computing Systems, (pp. 143-146). Vancouver, Canada: Conference Proceedings and Extended Abstracts. doi:https://doi. org/10.1145/1978942.1978963

Wohl, E., Lane, S., \& Wilcox, A. (2015). The science and practice of river restoration. Water Resource Research, 51, 5974 5997. https://doi.org/10.1002/2014WR016874.

Woolsey, S., Capelli, F., Gonser, T. O. M., Hoehn, E., Hostmann, M., Junker, B., \& Tockner, K. (2007). A strategy to assess river restoration success. Freshwater Biology, 52(4), 752769.

WWF; INTACH; Toxics Link; SANDRP; Peoples Science Institute; Peace Institute. (2019). Rejuvnating Ganga: A Citizen's Report.

Publisher's Note Springer Nature remains neutral with regard to jurisdictional claims in published maps and institutional affiliations. 